\title{
GRACILIS MUSCLE TRANSFER TO ELBOW FLEXION IN BRACHIAL PLEXUS INJURIES
}

\section{TRANSFERÊNCIA DO MÚSCULO GRÁCIL PARA FLEXÃO DO COTOVELO NAS LESÕES DO PLEXO BRAQUIAL}

\author{
Gustavo Bersani Silva ${ }^{1}$ (i), Maurício Rodrigues lima Neto ${ }^{1}$ (i), Alvaro Baik ChO ${ }^{1}$ (i), Raquel Bernardelli lamaguchi ${ }^{1}$ (i), \\ MARCELO ROSA DE RESENDE ${ }^{1}$ (1), TENG HSIANG WEI ${ }^{1}$ (D)
}

1. Universidade de São Paulo, Medical School, Hospital das Clínicas, Institute of Orthopedics and Traumatology, São Paulo, SP, Brazil.

\section{ABSTRACT}

Objective: Brachial plexus injury can lead to significant functional deficit for the patient. Elbow flexion restoration is a priority in surgical treatment. Free functional muscle transfer is an option for early or late treatment failure. This study evaluated patient characteristics and elbow flexion muscle strength after gracilis functioning muscle transfer. Methods: Medical records of 95 patients operated from 2003 to 2019 were analyzed and the following variables recorded: age, gender, nerve transfer used to motorize the gracilis muscle, time between trauma and surgery, age at surgery and elbow flexion strength after a minimum of 12 months following functioning muscle transfer. Results: 87 patients were included, averaging 30 years of age (17 to 57 years). Fifty-five achieved elbow flexion muscle strength $\geq$ M3 $(55 / 87,65 \%)$, with a mean follow-up of 37 months. The nerves used for activation of the transferred gracilis were: 45 spinal accessory, 10 intercostal, 8 median $n$. fascicles, 22 ulnar $n$. fascicles and 2 phrenic nerves. Conclusion: Functional muscle transfer is a viable surgical procedure for elbow flexion in chronic traumatic brachial plexus injuries in adults. Level of Evidence II, Retrospective study.

Keywords: Surgical flaps. Microsurgery. Brachial Plexus.
RESUMO

Objetivo: A lesão do plexo braquial pode determinar sequelas para o paciente. A restituição da flexão do cotovelo é prioridade no tratamento cirúrgico. A transferência muscular funcional livre é opção na falha do tratamento precoce ou tardio. Este estudo avaliou características dos pacientes e força muscular de flexão do cotovelo após transferência muscular funcional livre. Métodos: Prontuários de 95 pacientes, operados de 2003 a 2019, foram analisados e as seguintes variáveis registradas: idade, sexo, transferência nervosa utilizada para motorizar o músculo grácil, tempo entre o trauma e a cirurgia, idade na cirurgia, força de flexão do cotovelo após prazo mínimo de 12 meses da transferência muscular livre. Resultados: 87 pacientes foram incluídos no estudo, com idade média de 30 anos (17 a 57 anos). Cinquenta e cinco pacientes obtiveram força muscular de flexão de cotovelo $\geq$ M3 (55/87, 65\%), com tempo de seguimento médio pós-operatório de 37 meses. Os nervos utilizados para ativação do músculo grácil foram: 45 espinhais acessórios, 10 intercostais, oito fascículos do n. mediano, 22 fascículos do n. ulnar e dois frênicos. Conclusão: A transferência muscular funcional livre é um procedimento cirúrgico viável para flexão do cotovelo nas lesões traumáticas crônicas do plexo braquial no adulto. Nível de Evidência II, Estudo retrospectivo.

Descritores: Retalhos Cirúrgicos. Microcirurgia. Plexo Braquial.

Citation: Silva GB, Lima Neto MR, Cho AB, lamaguchi RB, Resende MR, Wei TH. Gracilis muscle transfer for elbow flexion in brachial plexus injuries. Acta Ortop Bras. [online]. 2020;28(4):165-7. Available from URL: http://www.scielo.br/aob.

\section{INTRODUCTION}

Traumatic injury of the brachial plexus has gained special attention from the scientific community in recent decades, not only for being a devastating pathology, but also because its treatment imposes remarkable challenges on the professional involved. ${ }^{1}$ Notably, elbow flexion deficit represents a frequent problem for most patients with brachial plexus injury, with its reestablishment being the primary objective of treatment. ${ }^{2}$
Graft reconstructions and nerve transfers for elbow flexion are the preferred approach in early treated brachial plexus injuries. ${ }^{3}$ However, patients evaluated late (trauma-surgery interval above 12-18 months) show degeneration of the neuro-muscular junction of the upper limb muscles, an irreversible change that precludes reconstructions and nerve transfers to this musculature. ${ }^{4}$ When treatment is delayed or the surgical treatment fails in the acute phase - and there are no muscles strong enough for muscle transfer - the alternative to recover elbow flexion is free functional

All authors declare no potential conflict of interest related to this article.

The study was conducted at Universidade de São Paulo, Medical School, Hospital das Clínicas (HC-FMUSP), Institute of Orthopedics and Traumatology.

Correspondence: Maurício Rodrigues Lima Neto. Rua Dr. Ovídio Pires de Campos, 333, Cerqueira Cesar, São Paulo, SP, Brazil, 05403010. mauriciolimaneto@hotmail.com 
muscle transplant with intraplexual or extra-plexual nerve transfer, depending on the severity of the brachial plexus injury. ${ }^{4-5}$ Opting for free functional muscle transfer, a donor motor nerve for the transferred muscle must be selected. Total brachial plexus injuries commonly uses the accessory nerve and the intercostal nerves. For high partial injuries, in addition to these nerves, motor fascicles of the median nerve or ulnar nerve can also be transferred. ${ }^{6}$ Currently, the free gracilis flap is the most popular choice for elbow flexion reconstruction - a thin muscle with adequate strength and excursion, reliable neurovascular pedicle, easy dissection, resulting in little functional loss of the lower limb. ${ }^{7}$ This study aimed to describe the patients' characteristics and the results of free gracilis muscle transfer to elbow flexion in chronic brachial plexus injuries in adults, after evaluating 87 consecutive cases performed at a university hospital.

\section{MATERIALS AND METHODS}

The study began after the formal authorization granted by the institution's and Plataforma Brasil Research Ethics Committee under CAAE 52633015.0.0000.0068 and after all patients have signed the informed consent form.

Between February 2003 and December 2019, 95 patients with traumatic brachial plexus injury underwent free transfer of the gracilis muscle to recover elbow flexion.

The following variables were retrospectively collected by medical records analysis: age, gender, trauma mechanism, injury laterality, injury level, nerve transfer used to motorize the gracilis muscle, interval between trauma and surgical procedure, patient's age during surgery, elbow flexion strength after a minimum of 12 months of free muscle transfer, relevant observations (complications, secondary surgeries, associated trauma, etc.).

The inclusion criteria for the study were: patients older than 18 years of age who received a functioning gracilis muscle flap for elbow flexion reconstruction following post-traumatic brachial plexus injury. Patients with failed free gracilis flap or having less than 12 months of postoperative follow-up at the time of evaluation were excluded. Results after secondary surgery (e.g., Steindler and distal retensioning of the gracilis muscle insertion) were discarded. Patients subjected to secondary surgeries were included considering only the results after free transfer from gracilis muscle, that is, before additional surgeries.

Two patients were excluded due to loss of the transferred free muscle $(2 / 95 ; 2 \%)$, one after venous thrombosis of the flap and one due to infection. Six other patients were excluded due to total postoperative follow-up of less than 12 months, totaling 87 patients included in the study.

Patients were divided into five groups according to the transferred nerve for activating the functional flap of the gracilis muscle: spinal accessory nerve (SAN), intercostal nerves (ICN), median nerve fascicle (MED), ulnar nerve fascicle (ULNAR) and phrenic nerve (PHR). The final elbow flexion muscle strength was assessed using the British Medical Research Council (BMRC) scale $^{8}$ (Table 1). Considering that a patient undergoing a free functional flap has no normal muscle strength, the authors classified the research subjects from MO to M4, deeming a good result M3 or more.

Table 1. British Medical Research Council (BMRC) Scale. ${ }^{8}$

\begin{tabular}{c|c}
\hline $\begin{array}{c}\text { Degree of } \\
\text { muscle strength }\end{array}$ & No muscle contraction \\
\hline M0 & Muscle contraction not resulting in joint movement \\
\hline M1 & Muscle contraction with movement excluding gravity \\
\hline M2 & $\begin{array}{c}\text { Muscle contraction effective against gravity } \\
\text { but does not overcome resistance. }\end{array}$ \\
\hline M3 & Muscle contraction that overcomes some resistance \\
\hline M4 & Normal muscle strength \\
\hline M5 &
\end{tabular}

\section{RESULTS}

Of the 87 cases included in the analysis, 82 patients were male (94.2\%) and 5 females (5.8\%). The mean age was 30 years (ranging from 17 to 57 years). Of the 87 patients, 48 showed left laterality (55.1\%) and 39 right laterality (44.9\%). Regarding injury characteristics, 42 patients had partial injury (48.2\%), 20 C5-6 injury (47\%) and 22 C5-7 (53\%), in addition to 45 presenting total injury (51.8\%).

Evaluating trauma mechanisms, we found 75 motorcycle accidents (86\%), five hit-and-run (5\%), two car accidents (3\%), two bicycle accidents (3\%) and two physical aggressions (3\%).

The mean interval between accident and surgery was 79 months (ranging from 8 to 1311 months). The mean follow-up time was 37 months (ranging from 13 to 154 months).

Regarding functional strength, 55 cases had muscle strength $\geq$ M3 (65\%): eight M0 (9\%), nine M1 (10\%), 15 M2 (17\%), 30 M3 (35\%) and 25 M4 (29\%).

The nerve transfers that activated free functional muscle flaps were: 45 spinal accessory nerve transfers (four using sural nerve graft and 41 cases without grafting), 10 intercostal nerves (three with graft and seven without), eight median nerve fascicles, 22 ulnar nerve fascicles and two phrenic nerves.

Table 2 summarizes the results of the different donor nerve transfers to the functional muscle flap.

Table 2. Results per transferred nerve.

\begin{tabular}{c|c|c|c|c|c|c}
\hline & Overall & SAN & ICN & MED & ULNAR & PHR \\
\hline $\begin{array}{c}\text { Good Result } \\
(\geq \text { M3) }\end{array}$ & $\mathbf{5 5 / 8 7}$ & $\mathbf{3 3 / 4 5}$ & $\mathbf{6 / 1 0}$ & $\mathbf{2 / 8}$ & $\mathbf{1 3 / 2 2}$ & $\mathbf{1 / 2}$ \\
$\mathbf{2}$ M0 & $8 / 87$ & $(\mathbf{7 3 . 3} \%)$ & $(\mathbf{6 0 . 0 \% )}$ & $\mathbf{( 2 5 . 0 \% )}$ & $\mathbf{( 5 9 . 0 \% )}$ & $\mathbf{( 5 0 \% )}$ \\
\hline \multirow{2}{*}{ M1 } & $(9 \%)$ & $(6.5 \%)$ & $3 / 10$ & $0 / 8$ & $1 / 22$ & $1 / 2$ \\
& $9 / 87$ & $4 / 45$ & $0 / 10$ & $2 / 8$ & $3 / 22$ & \\
& $(10 \%)$ & $(9.0 \%)$ & $(0.0 \%)$ & $(25.0 \%)$ & $(13.6 \%)$ & \\
\hline \multirow{2}{*}{ M2 } & $15 / 87$ & $5 / 45$ & $1 / 10$ & $4 / 8$ & $5 / 22$ & \\
& $(17 \%)$ & $(11.0 \%)$ & $(10.0 \%)$ & $(50.0 \%)$ & $(22.8 \%)$ & \\
\hline \multirow{2}{*}{ M3 } & $30 / 87$ & $22 / 45$ & $3 / 10$ & $1 / 8$ & $3 / 22$ & $1 / 2$ \\
& $(35 \%)$ & $(49.0 \%)$ & $(30.0 \%)$ & $(12.5 \%)$ & $(13.6 \%)$ & $(50.0 \%)$ \\
\hline \multirow{2}{*}{ M4 } & $25 / 87$ & $11 / 45$ & $3 / 10$ & $1 / 8$ & $10 / 22$ & \\
& $(29 \%)$ & $(24.5 \%)$ & $(30.0 \%)$ & $(12.5 \%)$ & $(45.5 \%)$ & \\
\hline
\end{tabular}

SAN: spinal accessory nerve; ICN: intercostal nerves; MED: median nerve. ULNAR: ulnar nerve; PHR: phrenic nerve.

The complications of the viable flaps were: four re-explorations three for loss of the skin monitor with the viable flap and one compressed pedicle by hematoma - and four infections (two from the recipient site and one from the donor site), totaling $9.2 \%$.

The secondary surgeries were: eight proximal transfers of the flexo-pronator muscles (Steindler surgery) - five cases going from $M 2$ to M4, two cases from M3 to M4, and one case that from M1 performed triceps to biceps transfer and after Steindler obtained final result of $\mathrm{M} 4$ - and one case of distal retensioning of the gracilis muscle insertion in the biceps tendon (without functional gain). Twelve patients who received free functional muscle transfer had previously undergone unsuccessful exploration and reconstruction of the brachial plexus (four graft reconstructions and eight nerve transfers).

\section{DISCUSSION}

This study reinforces the current understanding that traumatic brachial plexus injury primarily affects young men victimized in motorcycle accidents: $94.2 \%$ of the patients were male, with a mean age of 30 years. Flores ${ }^{9}$ and Anjos $^{10}$ evaluated the victims of motorcycle accidents in different Brazilian states, concluding that they are basically young males. Brachial plexus injury represents a 
major impact on these victims' lives ${ }^{10}$ due to the long treatment time and permanent functional deficit that it imposes on the injured. We believe that these demographic and natural history characteristics justify all efforts to try to restore the affected limb, even if partially. Based on Dyck et al., ${ }^{11}$ we used the British Medical Research Council (BMRC) scale to assess elbow flexion muscle strength. According to Bengtson et al., ${ }^{12}$ about three quarters of the publications that evaluate brachial plexus use this scale, being a simple and wellestablished method. An opinion shared by Bhardwaj et al., ${ }^{13}$ who state that this scale is the most popular to assess the return of elbow flexion, but alerting to the variances in inter-observer interpretation of the BMRC grading.

Ikuta et al. ${ }^{14}$ were the first to describe free functioning muscle transfer connected to intercostal nerves for elbow flexion reconstruction, with their initial report being followed by numerous publications that selected different nerve donor sources. ${ }^{10,15}$ Chung et al. ${ }^{16}$ reported free gracilis muscle transfer to elbow flexion using intercostal nerves as the donor, with $78 \%$ of patients reaching flexion strength M4 or higher; Krakauer et al. ${ }^{15}$ reported M3 or more in three of their four patients (75\%) while Chuang et al., ${ }^{17}$ studied 16 cases and $81.2 \%$ achieved $\mathrm{M} 3$ or more elbow flexion strength. Success rate ( $\geq \mathrm{M} 3)$ of the present study $(60 \%, 6 / 10)$ after intercostal nerve transfer to the transplanted gracilis was slightly lower than previously reported. Barrie et al. ${ }^{18}$ reviewed 26 patients who underwent free transfer of the gracilis muscle, with intercostal nerves or spinal accessory nerve as the donors, and reported functional elbow flexion in $63 \%$ of cases. Kay et al. ${ }^{19}$ studied 33 functioning transfers of the gracilis muscle, most of which were attached to intercostal nerves (15 cases) or ulnar nerve fascicles (12 cases) with an overall success rate ( $\geq \mathrm{M} 3)$ of $70 \%$; when only adults were included, this rate reached $53 \%$. Intercostal nerves group yielded better results regarding elbow flexion strength. In the present study the overall good results ( $\geq M 3)$ reached $65 \%$ while ulnar nerve fascicles transfer group achieved a success rate of $59 \%$, similar to the intercostal nerves group (60\%).
Sungpet et al. ${ }^{20}$ assessed the result of free gracilis transfer to elbow flexion in three patients with high brachial plexus injury (C5/C6), using an ulnar nerve fascicle as donor nerve. After a 33-month follow-up, an average elbow flexion muscle strength of $4.3 \mathrm{~kg}$ was observed. The authors reported no loss of hand grip strength or wrist flexion, as well as no change in sensitivity. The advantages of using the ulnar nerve as a donor are highlighted, being easy to perform, avoiding the use of nerve grafts and enabling voluntary control of elbow flexion. The authors of the present study report similar outcomes as ulnar nerve transfer proved to be a reliable procedure, with satisfactory results and no sensory-motor deficit of the donor nerve. Limitations of this study were its retrospective nature and the qualitative assessment of elbow flexion strength (even though the BMRC scale is vastly used in the literature). Likewise, the limited number of patients operated on in some groups (median, intercostal, and phrenic) hinder in-depth group comparison. Data from handwritten medical records was eventually challenging to interpret. The patients' individual effort during assessment and rehabilitation may impact the results.

Limitations of this study were its retrospective nature and the qualitative assessment of elbow flexion strength (even though the BMRC scale is vastly used in the literature). Likewise, the limited number of patients operated on in some groups (median, intercostal, and phrenic) hinder in-depth group comparison. Data from handwritten medical records was eventually challenging to interpret. The patients' individual effort during assessment and rehabilitation may impact the results.

\section{CONCLUSION}

The free functioning transfer of the gracilis muscle for traumatic brachial plexus injuries is a reliable surgical technique for gaining elbow flexion in adults. Further studies are needed to elucidate the role of accessory, intercostal, median, ulnar, and phrenic nerves in activating functional muscle flaps for upper limb reconstruction.

AUTHORS' CONTRIBUTIONS: Each author contributed individually and significantly to the development of this article. GBS: writing of the article; MRLN: data collection; ABC: study design; RBI: data analysis; MRR: project review; THW: intellectual concept and article review.

\section{REFERENCES}

1. Narakas AO. The treatment of brachial plexus injuries. Int Orthop. 1985;9(1):29-36.

2. Coulet B, Boch C, Boretto J, Lazerges C, Chammas M. Free Gracilis muscle transfer to restore elbow flexion in brachial plexus injuries. Orthop Traumatol Surg Res. 2011;97(8):785-92.

3. Teboul F, Kakkar R, Ameur N, Beaulieu JY, Oberlin C. Transfer of fascicles from the ulnar nerve to the nerve to the biceps in the treatment of upper brachial plexus palsy. J Bone Joint Surg Am. 2004;86(7):1485-90.

4. Bishop AT. Functioning free-muscle transfer for brachial plexus injury. Hand Clin. 2005;21(1):91-102.

5. Kimura LK, Nascimento AT, Capócio R, Mattar R Jr, Rezende MR, Wei TH, et al. Microsurgical transfer of the gracilis muscle for elbow flexion in brachial plexus injury in adults: retrospective study of eight cases. Rev Bras Ortop. 2011;46(5):534-9.

6. Chin $\mathrm{K}$, Vasdeki D, Hart A. Inverted free functional gracilis muscle transfer for the restoration of elbow flexion. J Plast Reconstr Aesthet Surg. 2013;66(1):144-6.

7. Manktelow RT, Zuker RM. The principles of functioning muscle transplantation: applications to the upper arm. Ann Plast Surg. 1989;22(4):275-82.

8. Medical Research Council. Aids to the examination of the peripheral nervous system, Memorandum No. 45. London: Her Majesty's Stationery Office; 1981.

9. Flores LP. Epidemiological study of the traumatic brachial plexus injuries in adults. Arq Neuropsiquiatr. 2006;64(1):88-94

10. Anjos KC. Implicações sociais e econômicas nos pacientes vítimas de acidentes com motocicleta internados no IOT-HCFMUSP [master's thesis]. São Paulo: Universidade de São Paulo; 2012.
11. Dyck PJ, Boes CJ, Mulder D, Millikan C, Windebank AJ, Dyck PJ, et al. History of standard scoring, notation, and summation of neuromuscular signs: a current survey and recommendation. J Peripher Nerv Syst. 2005;10(2):158-73.

12. Bengtson KA, Spinner RJ, Bishop AT, Kaufman KR, Coleman-Wood K, Kircher $\mathrm{MF}$, et al. Measuring outcomes in adult brachial plexus reconstruction. Hand Clin. 2008;24(4):401-15.

13. Bhardwaj $P$, Bhardwaj N. Motor grading of elbow flexion - is Medical Research Council grading good enough? J Brachial Plex Peripher Nerve Inj. 2009;4:3.

14. Ikuta Y, Yoshioka K, Tsuge K. Free muscle graft as applied to brachial plexus injurycase report and experimental study. Ann Acad Med Singapore. 1979;8(4):454-8.

15. Krakauer JD, Wood MB. Intercostal nerve transfer for brachial plexopathy. J Hand Surg Am. 1994;19(5):829-35.

16. Chung DC, Carver N, Wei FC. Results of functioning free muscle transplantation for elbow flexion. J Hand Surg Am. 1996;21(6):1071-7.

17. Chuang DC, Epstein MD, Yeh MC, Wei FC. Functional restoration of elbow flexion in brachial plexus injuries: results in 167 patients (excluding obstetric brachial plexus injury). J Hand Surg Am. 1993;18(2):285-91.

18. Barrie KA, Steinmann SP, Shin AY, Spinner RJ, Bishop AT. Gracilis free muscle transfer for restoration of function after complete brachial plexus avulsion. Neurosurg Focus. 2004;16(5):E8.

19. Kay S, Pinder R, Wiper J, Hart A, Jones F, Yates A. Microvascular free functioning gracilis transfer with nerve transfer to establish elbow flexion. J Plast Reconstr Aesthet Surg. 2010;63(7):1142-9.

20. Sungpet A, Suphachatwong C, Kawinwonggowit V. Transfer of one fascicle of ulnar nerve to functioning free gracilis muscle transplantation for elbow flexion. ANZ J Surg. 2003;73(3):133-5. 